\title{
Endocrine cells in diffuse pulmonary fibrosis
}

\author{
N J E Wilson, J R Gosney, F Mayall
}

\begin{abstract}
Background-There is evidence to suggest, particularly from studies in animals, that the products of pulmonary endocrine cells, especially gastrin releasing peptide, may have a role in the pathogenesis of fibrosis in the lung. This study was carried out to examine the morphology, number, distribution, and content of pulmonary endocrine cells in tissue from 49 patients with diffuse pulmonary fibrosis.
\end{abstract}

Methods-Twenty patients with interstitial pneumonitis, 17 with early fibrosis, and 12 with frank honeycombing were studied, together with five age matched controls without pulmonary disease. Endocrine cells were immunolabelled by the avidin-biotin complex method for two general markers (protein gene product 9.5 and neuron specific enolase) and a range of normal and aberrant secretory products.

Results-In the early stages, characterised by vigorous pneumonitis, endocrine cells were normal in appearance and distribution but very few in number. They contained only those secretory products normally found in such cells in health; inappropriate substances were not seen. By the time of early fibrosis endocrine cells were even fewer. None were identifiable in the lungs affected by honeycombing, despite the fact that all contained intact, well preserved epithelium.

Conclusions-It seems unlikely that the products of pulmonary endocrine cells can have any role in the pathogenesis of diffuse pulmonary fibrosis in man, the diminution in their number with advancing fibrosis probably reflecting their loss simply as a consequence of generalised epithelial damage.

(Thorax 1993;48:1252-1256)

The roles of pulmonary endocrine cells in healthy and diseased lungs remain unclear, but they are almost certainly involved in either the pathogenesis of, or response to, a range of pulmonary diseases. ${ }^{1}$ One condition in which they may perform an important function is pulmonary fibrosis, which occurs commonly in human lungs affected by various diseases. ${ }^{2}$
Increased numbers of pulmonary $\stackrel{\frac{\Phi}{\triangleright}}{\overrightarrow{8}}$ endocrine cells are found in rats when pulmonary fibrosis is induced by asbestos, ${ }^{34}$ and $\overrightarrow{0}$ the same phenomenon has been described in man around areas of non-specific localised $\omega_{\sigma}$ fibrosis in which aberrant substances may $\underset{F}{\vec{f}}$ appear within them..$^{5-7}$ In addition, pul- $x$ monary endocrine cell proliferation has been $\stackrel{+}{\circ}$ observed in conditions such as infantile $\vec{N}$ bronchopulmonary dysplasia ${ }^{8}$ and pulmonary $\vec{N}$ eosinophilic granuloma ${ }^{9}$ in which fibrosis is a N feature of the disease process. One of the 음 products of these cells, gastrin releasing peptide, is a powerful mitogen for fibroblasts $\square$ in vitro. ${ }^{10}$ It has been suggested that release of ${ }_{\varnothing}$ gastrin releasing peptide from proliferating 3 endocrine cells in situations such as these may be important in stimulating fibro- $\vec{\theta}$ genesis. ${ }^{8}$ We have investigated the morphol- $\frac{6}{\omega}$ ogy, number, distribution, and content of pulmonary endocrine cells in human lungs in the various stages of development of diffuse pulmonary fibrosis.

\section{Methods}

Fifty four pairs of lungs were studied, all obtained at necropsy. Five were control lungs unaffected by pulmonary disease, and $20=$ were lungs affected by pneumonitis of indeterminate cause in which the pulmonary interstitium was infiltrated by chronic inflam- $-\dot{\sigma}$ matory cells but showed no evidence of fibrosis. A further 17 were affected by grade 2 and $\delta$ grade 3 interstitial fibrosis in which the interstitium was thickened by the deposition of collagen. These were also of indeterminate $>$ cause. A final group of 12 patients had grade 4 fibrosis with frank honeycombing. All 12N patients with honeycomb lung died of their disease but, in the remaining 37 subjects with either pneumonitis or early fibrosis, the $\omega$ causes of death were wide ranging and unrelated to the pulmonary disease; the cases in question were taken from an archive stretch- $\cong$ ing back many years. It was access to this archive that allowed us to obtain relativelyo large amounts of tissue from subjects with $\frac{}{\Phi}$ pneumonitis and early fibrosis; usually this $\stackrel{\mathbb{\Phi}}{\circ}$ comes to the pathologist only as pulmonary biopsy tissue. In four pairs of honeycomb lungs resulting from asbestosis, asbestos fibres were numerous in all sections studied but were not seen in the tissue from any of the other lungs.

Ten blocks of tissue were taken from each pair of lungs, two from the mid zone of each 
lobe, and fixed in $10 \%$ neutral buffered formalin and embedded in paraffin wax. Sections were stained with haematoxylin and eosin and examined by light microscopy to ascertain the stage of fibrosis. Closely adjacent sections were immunochemically labelled by the avidin-biotin complex technique $^{11}$ for neuron-specific enolase and protein gene product 9.5 -general markers for cells of the diffuse endocrine system ${ }^{12}{ }^{13}$-and for a range of their secretory products. These included substances established as products of normal human pulmonary endocrine cells (gastrin releasing peptide, calcitonin, calcitonin gene-related peptide, and serotonin), together with several products which have been described in pulmonary endocrine cells in diseased lungs. ${ }^{57}$ The latter included adrenocorticotrophin, somatostatin, leucine enkephalin, growth hormone and arginine vasopressin.

Following treatment with hydrogen peroxide in methanol to inactivate endogenous peroxidase and with normal swine serum to prevent non-specific binding of antibody, sections were incubated with the primary antiserum for a variable period of time, dependent upon the nature and concentration of the antiserum being used. This was then linked to avidin-biotin complex by biotin-conjugated donkey antirabbit immunoglobulin. The chromogen used was 3',3'-diaminobenzidine tetrahydrochloride. Appropriate positive and negative tissue controls were employed in all cases. The source, working dilution, incubation period, and nature of the control tissues for each of the primary antisera are shown in the table.

Immunolabelled sections were examined by light microscopy and the morphology, distribution, and content of endocrine cells were noted.

There are various ways in which pulmonary endocrine cells can be quantitated. ${ }^{1}$ The most accurate is to express their number in terms of the total epithelial population (endocrine cells/10000 epithelial cells) or unit length of epithelium (endocrine cells $/ \mathrm{cm}$ epithelium) but, providing sampling is consistent and the lungs being studied are all collapsed or distended to the same extent, expressing cells per $\mathrm{cm}^{2}$ tissue section is quite appropriate. All blocks used in this study were taken from the mid zones of the pulmonary lobes so that, apart from those in which honeycombing had destroyed the pulmonary architecture, all contained sections of intrapulmonary bronchi and terminal and respiratory bronchioles in generally equivalent proportions, together with a considerable amount of parenchyma. In addition, our previous studies of endocrine cells in diseased lungs have shown that, when they increase in number, they appear with some frequency in alveolar ducts and alveoli, whereas in normal lungs they are usually absent. ${ }^{1}$ In this location they are impossible to quantitate in terms of epithelial cells or epithelial length, and the only appropriate method of assessing their number is to express them per $\mathrm{cm}^{2}$. For these reasons it was considered appropriate to express endocrine cells per $\mathrm{cm}^{2}$ of tissue section.

\section{Results}

Immunolabelling for neuron-specific enolase and protein gene product 9.5 revealed endocrine cells in the control lungs to be regularly but sparsely distributed throughout the pulmonary tree, although they were most prevalent in small intrapulmonary bronchi and none were identified in parenchyma. Most were solitary cells; only three clusters were seen in all 10 lungs examined. The number of cells in these five pairs of lungs ranged from 7 to $15 / \mathrm{cm}^{2}$ tissue section with a mean of 10 . About $60 \%$ of them contained gastrin releasing peptide and almost all of the rest calcitonin. No aberrant peptides were identified. This picture is typical of that seen in healthy adult human lungs. ${ }^{1}$

Details of antisera used in study

\begin{tabular}{|c|c|c|c|c|}
\hline Antigen & Source of antiserum & $\begin{array}{l}\text { Working } \\
\text { dilution }\end{array}$ & Incubation & $\begin{array}{l}\text { Control } \\
\text { tissue }\end{array}$ \\
\hline Neuron-specific enolase & $\begin{array}{l}\text { Dako Corporation } \\
\text { High Wycombe, Bucks, UK }\end{array}$ & $1: 200$ & $45 \mathrm{~min}$ & Human pancreas \\
\hline Protein gene product 9.5 & $\begin{array}{l}\text { Biogenesis } \\
\text { Bournemouth, UK }\end{array}$ & $1: 2000$ & Overnight $(18 \mathrm{~h})$ & Human pancreas \\
\hline Gastrin releasing peptide & $\begin{array}{l}\text { Peninsula Laboratories } \\
\text { St Helens, Merseyside, UK }\end{array}$ & $1: 4000$ & Overnight (18 h) & Human fetal lung \\
\hline Calcitonin & $\begin{array}{l}\text { Dako Corporation } \\
\text { High Wycombe, Bucks, UK }\end{array}$ & $1: 2000$ & $45 \mathrm{~min}$ & $\begin{array}{l}\text { Medullary } \\
\text { carcinoma } \\
\text { of thyroid }\end{array}$ \\
\hline $\begin{array}{l}\text { Calcitonin gene-related } \\
\text { peptide }\end{array}$ & $\begin{array}{l}\text { Peninsula Laboratories } \\
\text { St Helens, Merseyside, UK }\end{array}$ & $1: 4800$ & $45 \mathrm{~min}$ & $\begin{array}{l}\text { Medullary } \\
\text { carcinoma } \\
\text { of thyroid }\end{array}$ \\
\hline Serotonin & $\begin{array}{l}\text { Peninsula Laboratories } \\
\text { St Helens, Merseyside, UK }\end{array}$ & $1: 1000$ & $45 \mathrm{~min}$ & Human ileum \\
\hline Adrenocorticotrophin & $\begin{array}{l}\text { Dako Corporation } \\
\text { High Wycombe, Bucks, UK }\end{array}$ & $1: 1000$ & $45 \mathrm{~min}$ & $\begin{array}{l}\text { Human } \\
\text { adenohypophysis }\end{array}$ \\
\hline Somatostatin & $\begin{array}{l}\text { Seralab } \\
\text { Crawley Down, Sussex, UK }\end{array}$ & $1: 1600$ & $45 \mathrm{~min}$ & Human pancreas \\
\hline Leucine enkephalin & $\begin{array}{l}\text { CRB } \\
\text { Northwich, Cheshire, UK }\end{array}$ & $1: 800$ & $45 \mathrm{~min}$ & $\begin{array}{l}\text { Human adrenal } \\
\text { medulla }\end{array}$ \\
\hline Growth hormone & $\begin{array}{l}\text { Dako Corporation } \\
\text { High Wycombe, Bucks, UK }\end{array}$ & $1: 800$ & $45 \mathrm{~min}$ & $\begin{array}{l}\text { Human } \\
\text { adenohypophysis }\end{array}$ \\
\hline Arginine vasopressin & $\begin{array}{l}\text { ICN Biochemicals } \\
\text { High Wycombe, Bucks, UK }\end{array}$ & $1: 2000$ & $45 \mathrm{~min}$ & $\begin{array}{l}\text { Human } \\
\text { neurohypophysis }\end{array}$ \\
\hline
\end{tabular}



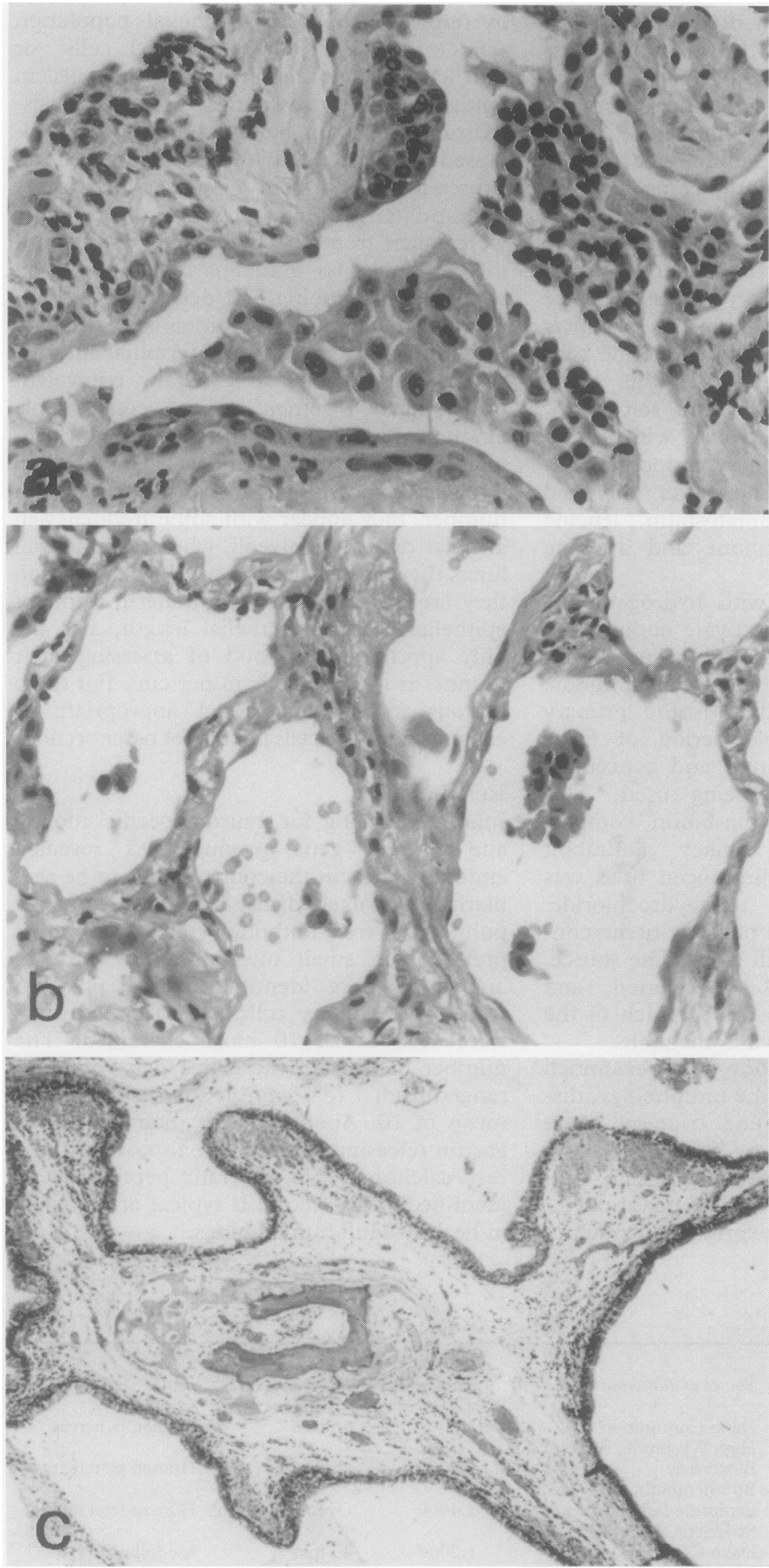

Figure 1 Typical appearances of the three groups of diseased lungs studied: (a) early stage of pneumonitis with, in this case, a prominent desquamative component; (b) early fibrosis of alveolar walls; and (c) lower power view of a typical example of coarse fibrosis with honeycombing. Haematoxylin and eosin; original magnification $\times 700 ; \times 550$; $\times 50$, increased to $114 \%$ during origination

Endocrine cells were identified in just four of the 20 pairs of lungs affected by pneumonitis (fig 1a). In these four cases the cells contained gastrin releasing peptide, or calcitonin, or both; no inappropriate secretory products were identified. They were individually normal (fig 2) and distributed regularly but sparsely, a picture indistinguishable from that seen in the control lungs. In one case there was a single, localised area in which there was a significant increase in their number (fig 3), but this was associated with an area of pneumonic consolidation. When just the four pairs of lungs in which endocrine cells were found were considered, their numbers ranged from $4-21 / \mathrm{cm}^{2}$ with a mean of $10 / \mathrm{cm}^{2}$ tissue section. When the whole group of 20 showing pneumonitis was considered the mean was two cells $/ \mathrm{cm}^{2}$ tissue.

In three of the 17 pairs of lungs affected by early interstitial fibrosis (fig 1b) endocrine cells were again normal in morphology and distribution and contained the same two peptides as were found in the lungs affected by pneumonitis. Other secretory products could not be shown. No cells were seen in the tissue from the remaining 14 pairs of lungs affected by interstitial fibrosis. When just the three pairs with identifiable endocrine cells were considered, they contained between six and eight endocrine cells $/ \mathrm{cm}^{2}$ with a mean of seven. When all 17 were considered, the mean was just one.

No pulmonary endocrine cells were identified in any of the 12 cases of "honeycomb lung" (fig 1c) despite the fact that all contained numerous strips of well preserved epithelium lining the abnormal spaces (fig 4).

\section{Discussion}

In conditions in which diffuse pulmonary fibrosis arises details of the underlying fibrogenic process are poorly understood, although stimulation of fibroblast activity is a key step and a number of different mechanisms and chemical mediators has been proposed. ${ }^{2}$ One possible mediator is gastrin releasing peptide, the mammalian equivalent of bombesin, which is a powerful mitogen for 3T3 fibroblasts in vitro. ${ }^{10}$ For example, Day et al $^{1415}$ have shown a 2-2.5 times increase in the levels of extractable bombesin in the lungs of rats exposed to asbestos, and studies of pulmonary endocrine cells in animals similarly exposed describe changes which also suggest a role for their products in pulmonary fibrosis. Thus, Johnson et $a l^{3}$ and Sheppard et $\mathrm{al}^{4}$ have described increased numbers of these cells, identified by electron microscopy and immunolabelling for neuron-specific enolase respectively, in the fibrotic lungs of rats with experimentally induced asbestosis.

It is tempting to associate proliferation of pulmonary endocrine cells and elevated levels of extractable bombesin with the development of fibrosis, but there are problems with this hypothesis. For example, the elevation of levels of extractable bombesin reported by Day et al ${ }^{14} 15$ occurred not when fibrogenesis was most active, but after 6-9 months of exposure when it was well established. In addition, and more fundamentally, no bombesin-like peptide has yet been identified in the pulmonary endocrine cells of rodents, and its source in the above studies is unclear.

Results of studies of naturally occurring 


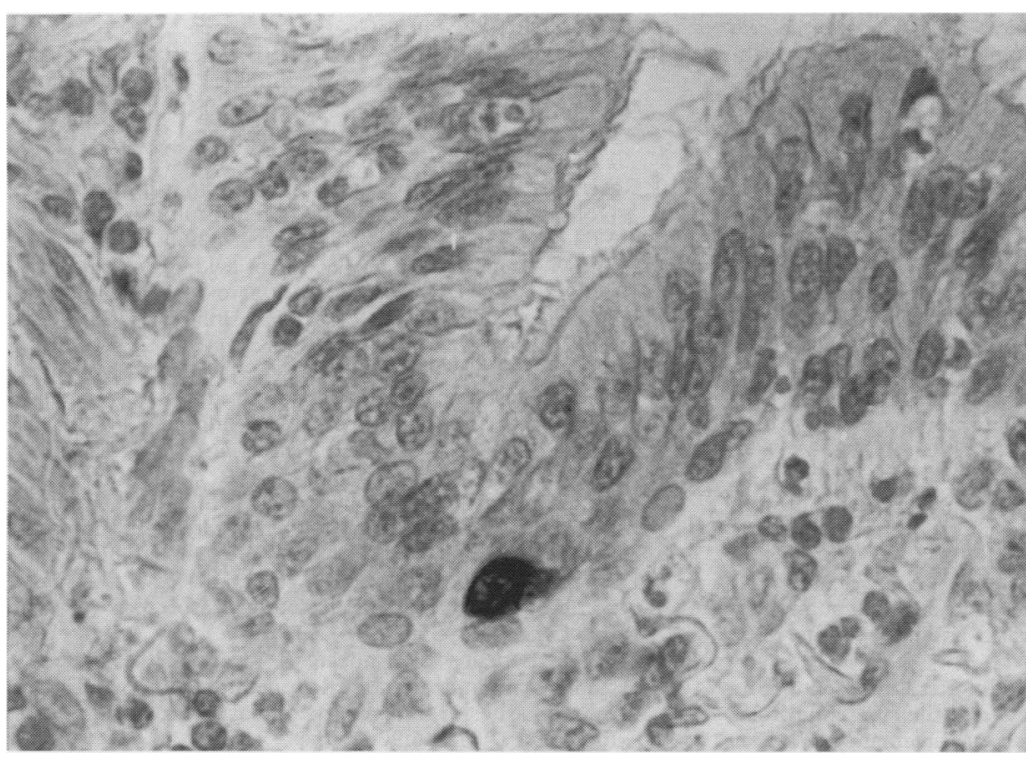

Figure 2 Morphologically normal solitary pulmonary endocrine cell from a lung affected by interstitial pneumonitis. Avidin-biotin complex for neuron-specific enolase; original magnification $\times 750$, increased to $130 \%$ during origination.

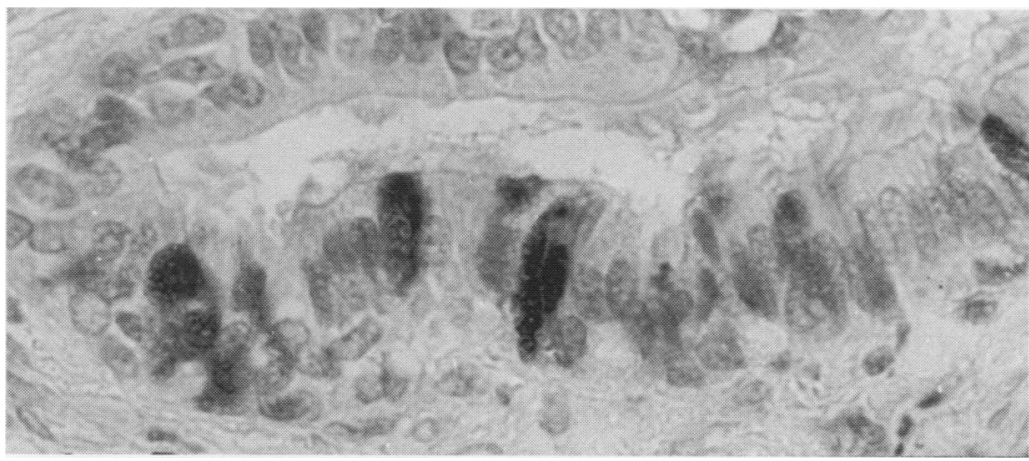

Figure 3 Interrupted row of endocrine cells in epithelium lining an inflamed airway in an area of pneumonia. Avidin-biotin complex for neuron-specific enolase; original magnification $\times 550$, increased to $122 \%$ during origination.

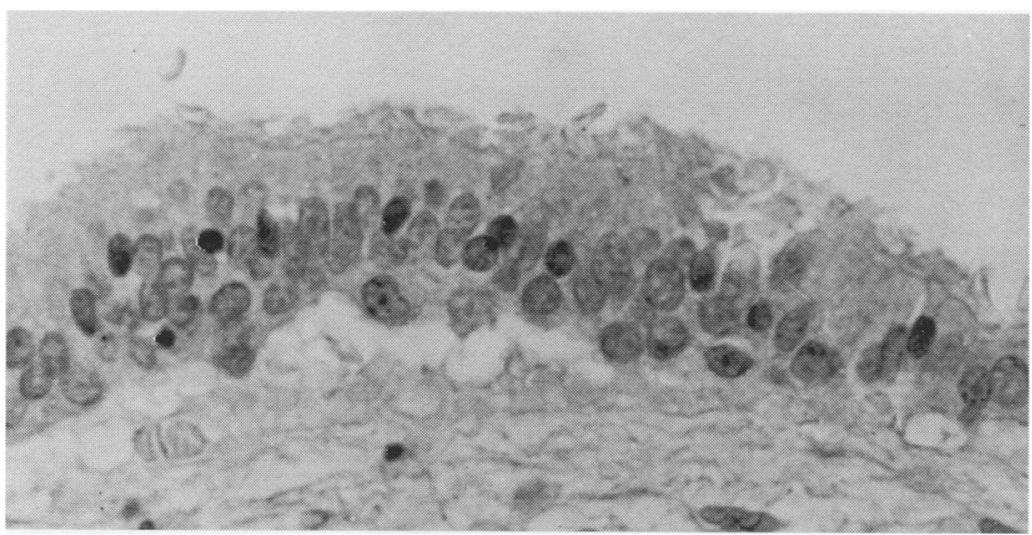

Figure 4 Strip of intact epithelium lining an abnormal space in a "honeycomb" lung. Despite the prevalence of such intact epithelium in these lungs, no endocrine cells were identifiable. Avidin-biotin complex for neuron-specific enolase; original magnification $\times 550$, increased to $136 \%$ during origination.

respiratory disease in man have also been interpreted as supporting a role for gastrin releasing peptide in pulmonary fibrogenesis. In bronchopulmonary dysplasia, for example, a condition of infancy in which fibrosis is a prominent feature, Johnson et $a l^{8}$ have shown a three fold increase in pulmonary endocrine cells containing gastrin releasing peptide. Aguayo et $a l^{9}$ found a tenfold increase in pulmonary endocrine cells with bombesinlike immunoreactivity compared with controls in adults with eosinophilic granuloma. Tsutsumi et $a l^{5}$ found a proliferation of gastrin releasing peptide-containing endocrine cells in four out of nine lungs containing areas of non-specific fibrosis.

In the light of the results of these previous investigations, the paucity of endocrine cells in the lungs affected by pneumonitis and interstitial fibrosis and their absence from those destroyed by end stage fibrosis in the present study seems initially difficult to explain. It is possible that the methods we used to identify these cells failed to do so, but this is highly unlikely, both protein gene product 9.5 and neuron-specific enolase being excellent labels for them. ${ }^{1}$ It is possible also that our sampling was responsible, the airways and parenchyma contained in the sections we examined being unrepresentative. However, all sections contained well preserved lengths of epithelium, even those from the lungs with honeycombing, and the classes of airways included in them are relatively well endowed with endocrine cells in normal lungs, notwithstanding the well documented variability in their concentration at different levels of the respiratory tree. ${ }^{1}$

It is interesting to note that Aguayo et al ${ }^{9}$ were also unable to show any significant increase in pulmonary endocrine cells in the lungs of eight patients with idiopathic diffuse pulmonary fibrosis which were included in their study of eosinophilic granuloma. Indeed, in their investigation these were actually used as controls.

We believe it is probable that the pulmonary endocrine system and the peptides it secretes are involved, not in fibrosis, but in the response to infection in the lung and the regeneration of damaged pulmonary tissues. In nearly all the conditions in which increased numbers of these cells have been described in human lungs, either acute or chronic inflammation due to infection or, more often, vigorous regeneration, especially of epithelium, have been present. Indeed, in the present study the single focus of endocrine cell proliferation that we identified surrounded, and was strictly localised to, an area of infective consolidation.

The paucity of endocrine cells in the lungs affected by pneumonitis and early interstitial fibrosis in the present study is probably simply a reflection of epithelial damage. The absence of these cells from the epithelium lining the abnormal air spaces in the lungs affected by honeycombing is interesting and has not been previously noted. Perhaps it reflects the abnormal environment in which this epithelium exists.

Nowhere, to our knowledge, have changes in the human pulmonary endocrine system been described in lungs affected by sterile inflammation or purely by fibrosis, and studies in animals are simply not comparable. A role for the products of pulmonary endocrine cells in inducing pulmonary fibrosis in man seems unlikely. 
1 Gosney JR. Pulmonary endocrine pathology: endocrine cells and endocrine tumours of the lung. Oxford: Butterworth Heinemann, 1992.

2 Dunnill MS. Pulmonary fibrosis. Histopathology 1990;16 321-9.

3 Johnson NF, Wagner JC, Wills HA. Endocrine cell proliferation in the rat lung following asbestos inhalation. Lung 1980;158:221-8.

4 Sheppard MN, Johnson NF, Cole GA, Bloom SR, Marangos PJ, Polak JM. Neuron specific enolase immunostaining. A useful tool for the microscopical detection of endocrine cell hyperplasia in adult rat exposed to asbestos. Histochemistry 1982;74:505-13.

5 Tsutsumi Y, Osamura RY, Watanabe K, Yanaihara N. Immunohistochemical studies on gastrin-releasing peptide and adrenocorticotropic hormone-containing cells in the human lung. Lab Invest 1983;43:623-32.

6 Fukayama M, Hayashi Y, Shiozawa Y, Furukawa E, Funata N, Koike $M$. Human chorionic gonadotropin $a$-subunit in endocrine cells of fibrotic and neoplastic lung. Lab Invest 1990;62:444-51.

7 Gould VE, Linnoila RI, Memoli VA, Warren WH. Neuroendocrine components of the bronchopulmonary tract: Hyperplasias, dysplasias and neoplasms. $L a b$ Invest 1983;49:519-37.

8 Johnson DE, Georgieff MK. Pulmonary neuroendocrine cells. Their secretory products and their potential roles in health and chronic lung disease in infancy. $A m$ Rev
Respir Dis 1989;140:1807-13.

9 Aquayo SM, King TE, Waldron JE, Sherritt KM, Kane MA, Miller YE. Increased pulmonary neuroendocrine cells with bombesin-like immunoreactivity in adult patients with eosinophilic granuloma. F Clin Invest 1990;86:838-44

10 Rozengurt E, Sinnett-Smith J. Bombesin stimulation of DNA synthesis and cell division of cultures of Swis 3T3 cells. Proc Natl Acad Sci USA 1983;80:2936-40.

$11 \mathrm{Hsu}$ SM, Raine L, Fanger H. Use of avidin-biotin peroxidase complex (ABC) in immunoperoxidase techniques: a comparison between $\mathrm{ABC}$ and unlabelled antibody (PAP) procedures. $\mathcal{F}$ Histochem Cytochem 1981;29:577-80.

12 Wharton J, Polak JM, Cole GA, Marangos PJ, Pearse AGE. Neuron-specific enolase as an immunocytochemical marker for the diffuse neuroendocrine system in human fetal lung. $\mathcal{F}$ Histochem Cytochem 1981;29. 1359-64.

13 Thompson RJ, Doran JF, Jackson P, Dhillon AP, Rode J. PGP 9.5, a new marker for vertebrate neurones and neuroendocrine cells. Brain Res 1983;278:224-8.

14 Day R, Lemaire I, Masse S, Lemaire S. Pulmonary bombesin in experimentally induced asbestosis in rats. Exp Lung Res 1985;8:1-13.

15 Day $R$, Lemaire S, Nadeau D, Keith I, Lemaire Changes in autacoid and neuropeptide contents of lung cells in asbestos-induced pulmonary fibrosis. $A m R e v$ Respir Dis 1987;136:906-15. 